\title{
Priority nursing foci and interventions for older people in acute care settings
}

Focos de atenção prioritários e ações de enfermagem dirigidos à pessoa idosa em contexto clínico agudo

Focos de atención prioritarios y acciones de enfermería dirigidas a la persona anciana en un contexto clínico agudo

Arménio Guardado Cruz*; António Marcos Tosoli Gomes**; Pedro Miguel Santos Dinis Parreira***

\begin{abstract}
Background: Priority nursing foci in acute care delivery to older patients are influenced by multiple factors, which may compromise care quality.

Objectives: To describe nurses' perception of the priority foci in the most frequent nursing interventions aimed at older inpatients in acute care settings, as well as to identify the association between priority nursing foci and other variables.

Methodology: Exploratory, descriptive, correlational study using a non-random convenience sample of 124 nurses $(q=100,80.6 \% ; M=29.8$ years; $S D=6.75)$. A questionnaire was used to assess nurses' perception of self-care priorities, and the frequency and importance of nursing interventions.

Results: The most important self-care priorities were self-grooming, self-dressing/undressing, and self-transferring. Significant differences were found between frequency and importance in the nursing interventions of attending $(Z=-3.272$; $p=0.001)$ and informing $(Z=-4.824 ; p=0.000)$. Significant negative correlations were found between self-grooming and nurses' age $\left(r_{s}=-0,203 ; p=0.032\right)$, length of service $\left(r_{s}=-0,194 ; p=0.041\right)$, and the number of nursing care hours per older patient week $(r=-0.257 ; p=0.007)$.

Conclusion: Nurses' initial and lifelong training, together with institutional strategies, should be based on a new paradigm.
\end{abstract}

Keywords: aged; hospitalization; acute disease; nursing diagnosis; self-care

\section{Resumo}

Enquadramento: As prioridades dos focos de atençáo dos enfermeiros nos cuidados agudos a pessoas idosas são influenciadas por diversos fatores, e podem colocar em risco a sua qualidade.

Objetivos: Descrever a perceção dos enfermeiros sobre prioridades dos focos de atenção das intervençôes de enfermagem mais comuns, dirigidos à pessoa idosa hospitalizada em fase aguda, e identificar associaçóes com outras variáveis.

Metodologia: Estudo exploratório-descritivo e correlacional. Amostra não aleatória de conveniência de 124 enfermeiros ( $Q=100,80,6 \% ; M=29,8$ anos; $D P=6,75$ ). Utilizou-se um questionário para avaliar a perceçáo de prioridades de autocuidados e a regularidade e importância das açóes de enfermagem.

Resultados: Prioridades mais elevadas nos autocuidados arranjar-se, vestir/despir e transferir. Diferenças significativas entre a regularidade e a importância nas açōes atender $(Z=-3,272 ; p=0,001)$ e informar $(Z=-4,824 ; p=0,000)$. Correlaçóes negativas significativas entre o autocuidado arranjar-se, a idade $(r=-0,203 ; p=0,032)$, o tempo de profissão $(r=-0,194 ; p=0,041)$, e as horas semanais de prestaçáo de cuidados a idosos $(r=-0,257 ; p=0,007)$.

Conclusáo: A formaçáo inicial e contínua, associada a estratégias institucionais, deve basear-se num novo paradigma.

Palavras-chave: idoso; hospitalização; doença aguda; diagnósticos de enfermagem; autocuidado

*Ph.D., Coordinating Professor, Nursing School of Coimbra, 3046-851, Coimbra, Portuga [acruz@esenfc.pt]. Contribution to the article: data analvsis, discussion, and article writing. Address for correspondence: Rua Dr. Paulo Quintela, 257, 1 P, 3030-393, Coimbra ting. Addr
Portugal.

Portugal. de Janeiro, Brazil [mtosoli@gmail.com]. Contribution to the article: data analysis, discussion, and article writing.

***:Ph.D., Adjunct Professor, Nursing School of Coimbra, 3046-851, Coimbra, Portugal [parreira@esenfc.pt].Contribution to the article: data analysis, discussion, and article writing.

\section{Resumen}

Marco contextual: Las prioridades de los focos de atención de los enfermeros en los cuidados agudos a las personas ancianas se ven influenciadas por diversos factores que pueden poner en riesgo su calidad.

Objetivos: Describir la percepción de los enfermeros sobre las prioridades de los focos de atención de las intervenciones de enfermería más comunes, dirigidos a la persona anciana hospitalizada en fase aguda, e identificar asociaciones con otras variables.

Metodología: Estudio exploratorio-descriptivo y correlacional. Muestra no aleatoria de conveniencia de 124 enfermeros $(q=100,80,6 \%, M=29,8$ ańos, $D T=$ $6,75)$. Se utilizó un cuestionario para evaluar la percepción de las prioridades de los autocuidados y la regularidad e importancia de las acciones de enfermería.

Resultados: Prioridades más altas en los autocuidados arreglarse, vestir / desnudar y transferir. Diferencias significativas entre la regularidad y la importancia en las acciones $(Z=-3,272 ; p=0,001)$ e informar $(Z=-4,824$; $p=0,000)$. Correlaciones negativas significativas entre el autocuidado arreglarse, la edad $(r=-0,203, p=$ $0,032)$, el tiempo de profesión $\left(r_{s}=-0,194, p=0,041\right)$, y las horas semanales de atención a ancianos $\left(r_{s}=-0,257\right.$; $p=0,007$ ).

Conclusión: La formación inicial y continua, asociada a estrategias institucionales, debe basarse en un nuevo paradigma.

Palabras clave: anciano; hospitalización; enfermedad aguda; diagnóstico de enfermería; autocuidado

\section{Received for publication: 06.06.17}

Accepted for publication: 06.09.17 


\section{Introduction}

The demographic changes that have occurred in recent years, and the estimates for the upcoming decades have contributed to the increase in hospital readmissions and rehospitalizations. These changes are particularly relevant when taking into account population ageing and the increased prevalence of chronic diseases, which are characterized by remission and exacerbation stages. In addition, readmission rates are significantly higher in older patients $(11.61 \%)$ than in the general population (4.45\%; Assunção, 2015).

The specific characteristics of this population group require a change in nurses' attitudes and interventions and a greater emphasis on new nursing foci, not only in general care delivery, but also in acute care settings. However, the current nurse-to-patient ratio (5.8 nurses/1,000 inhabitants) in Portugal, which is below the average in Organisation for Economic Co-operation and Development (OECD) countries in 2014, is a major barrier to this change as it is expected to continue decreasing, particularly in the National Health Service (Observatório Português dos Sistemas de Saúde (OPSS), 2015).

For this reason, the phenomenon of older people with health problems should be analyzed from a comprehensive and cross-sectional perspective in order to identify the most relevant nursing foci and produce the necessary evidence to improve prevention, treatment, and rehabilitation interventions within the health/illness transition process (Passos, Sequeira, \& Fernandes, 2014).

The accurate identification of nursing foci is essential to identifying a problem or specific need and making a diagnosis to plan the appropriate care.

Studies conducted in Portugal on the aging/selfcare phenomenon emphasize the need for more in-depth studies to better understand every dimension of this phenomenon from a clinical perspective that is more relevant to nursing care (Petronilho, 2012).

In this context, the identification of older inpatients' mobility-related needs is essential to enhance the acquisition of the necessary skills to preserve self-care autonomy, through the prevention of complications and promotion of physical, mental, and social health, but also to improve their quality of life.
Therefore, this study aims at identifying and describing nurses' perception of priority foci in the most frequent nursing interventions during care delivery to older inpatients in acute care settings, as well as identifying associations between these nursing foci and nurses' demographic and professional characteristics.

\section{Background}

The Portuguese population has been aging fast in recent decades, and estimates for 2015-2080 are even more worrying. In fact, the aging rate is expected to more than double, rising from 147 to 317 older people per 100 youths. Life expectancy at birth will be 80.62 years, the population pyramid will become increasingly inverted, with around $40-50 \%$ of people aged 65 years or over and only around $30 \%$ of children and young people, and the working age population will decrease from 6.7 to 3.8 million people (Instituto Nacional de Estatística, 2017).

People live longer, but older people have multiple chronic diseases that are associated with disability, functional decline, poorer quality of life, and higher health-related costs (Busse et al.; Marengoni et al., as cited in Tavares, 2014). In addition, chronic diseases are also associated with increased risk of hospitalization in the acute phases. In fact, according to Pignatelli (as cited in Carvalhais \& Sousa, 2011), older people are the most frequent health care users. In Portugal, estimates point to more than 75,000 rehospitalizations every year, with about half of these cases involving people aged 65 years or over and 290,000 cases involving stays of more than 7 days.

Since older people are the most frequent users of inpatient care, they are exposed to the complexity of the hospital system and contributing factors. In fact, the cause for older people's functional decline (FD) is multifaceted, for which the hospital administration, the health teams, and the older person him/herself share responsibility (Carvalhais \& Sousa, 2011).

The existing evidence has identified some risk factors for FD related to hospitalization: demographic factors, cognitive and psychological status, functional status before hospitalization, social factors, comorbidity and polypharmacy, mobility, nutritional status, sensory deficits, and 
geriatric syndromes (Lafont, Gérard, Voisin, Pahor, \& Vellas, 2011).

According to Admi, Shadmi, Baruch, and Zisberg (2015), there are several risk factors for FD during hospitalization, namely personal and psychosocial risk factors, as well as factors related to acute care settings. The most commonly reported personal risk factors include age, low activity of daily living (ADL) or instrumental activity of daily living (IADL), and nutritional status (Hoogerduijn et al., 2012).

Osuna-Pozo, Ortiz-Alonso, Vidán, Ferreira, and Serra-Rexach (2013) have reported that older people's main risk factors for FD associated with hospitalization are advanced age, lack of mobility, cognitive changes, and functional status prior to hospitalization.

Recent studies conducted with older inpatients in acute care settings (medicine and surgery units) found an increase of FD in ADLs and IADLs when comparing FC before admission, during hospitalization, and after clinical discharge (Cação, 2017).

Depressive symptoms seem to be the most common psychosocial risk factors among older inpatients, taking into account that hospital settings may cause patients to feel worthless, fearful, and not in control of what is happening (Helvik, Skancke, \& Selbaek; and Bridges, Flatley, \& Meyer, as cited in Admi et al., 2015). According to the same authors, the involvement of informal caregivers during hospitalization may be essential. However, while informal caregivers can have a positive effect on patients' cognitive status and depressive symptoms, they can also have a negative impact related to length-of-stay or rehospitalization.

Social representations (SRs) can influence nursing care, and negative SRs of aging can affect nursing care regarding the promotion of older people's engagement in self-care and decision-making. Therefore, in order to improve the quality of nursing care, nurses should assess their own attitudes and behaviors towards aging (Cruz, Tosoli, \& Parreira, 2015).

In acute care settings, as a result of the changes in health condition, which may lead to a disease situation, older patients go through transition processes that can influence their motor, cognitive, and affective functions and, in turn, their self-care ability (Abreu, 2011).

Self-care is both the focus and the outcome of health promotion and illness management interventions aimed at improving individuals' physical and psychosocial health problems, as well as their overall health status (Sidani, as cited in Petronilho, 2012).

From this perspective, self-care represents a theoretical foundation for psychoeducational, cognitive, and behavioral interventions. These interventions require the planning of learning activities designed to enhance individuals knowledge and skills to make decisions concerning the transitions over the lifecycle. Nurses' contribution to health care quality requires a paradigm shift in nursing, centered on the individual's transition processes triggered by health-related events, or the incorporation of new roles (Meleis, as cited in Petronilho, 2012).

Nursing foci (e.g., mobility, feeding, elimination, hygiene, etc.) are essential to determine nursing diagnoses, which, in turn, support care planning (Conselho Internacional de Enfermeiros, 2011). According to Passos et al. (2014, p. 83) "the correct identification of a nursing focus is a key step towards the recognition of a problem or specific need and the development of a diagnosis which allows for the planning of an appropriate response".

On the other hand, the outcomes that nurses expect to obtain from their interventions can result from the individuals' adequate actions and behaviors towards the achievement of health gains. Therefore, self-care can also be considered as a nursing care-sensitive outcome. (Irvine et al., Johnson \& Maas, Mitchell et al., as cited in Sidani, 2011).

Petronilho, Magalhães, Machado, and Vieira (2010) conducted a study using a sample of 40 older people admitted to several hospital units following a critical event. The sampled inpatients showed a higher level of self-care dependence in physical activities, namely in the following nursing foci: walking and self-transferring $(n=31$; $77.5 \%)$, self-dressing $(n=28 ; 70.0 \%)$, and self-toileting $(n=23 ; 57.5 \%)$. On the other hand, they showed greater autonomy in self-feeding $(n=13 ; 32.5 \%)$.

According to Kleinpell (as cited in Tavares, 2014), during older people's hospitalization, nurses and other professionals focus on resolving the acute problem, paying less attention to risk assessment and prevention of complications. Some studies indicate that health professionals, 
particularly nurses, spend little time in getting to know the older person, mainly because clinical settings prioritize the technical dimension rather than the development of a relationship that allows assessing and managing care while taking into account the older patients and their family context (Doherty-King \& Bowers; and Mallidou et al., as cited in Tavares, 2014).

In a study conducted in a central hospital using a sample of 177 nurses, Duque (2009) aimed identify the nurses' perception of the frequency and importance of a set of nursing self-care interventions. The author reported that attending, performing, and observing were the most frequent interventions, whereas informing and managing were implemented with a less-than-desirable frequency. According to the nurses' perceptions, some interventions (attending, performing, and observing) were implemented more often than necessary, while others (informing and managing) were implemented less often than desirable. With regard to self-care, these results suggest that nurses take on a role of acting for or instead of the patient, rather than creating the desired nurse-patient partnership and promoting self-care skills through patient education. On the other hand, the planning and systematization of nursing interventions to promote self-care are somewhat inconsistent because many activities are perceived by the nurses as being often implemented and, at the same time, as less important and vice-versa.

Although there is a global rehabilitative philosophy of care with which nurses help patients to actively engage in multiple self-care activities (bathing, dressing/undressing, mobility in bed, walking, etc.), nurses often perform the tasks for the patients instead of helping them to accomplish certain activities (Boltz, Resnick, Capezuti, Shabbat, \& Secic, 2011).

In this context, health professionals, particularly nurses, should improve their initial and lifelong training in order to acquire a more positive and appropriate perspective, from the completely healthy to the dependent older person (Carvalhais $\&$ Sousa, 2011). Furthermore, Faria (2012) emphasizes the need to increase knowledge about the aging process in order to demystify prejudice and fight against negative SRs of the older population. Adequate training and technical preparation are essential to promote new values that strengthen the social and professional construct.

\section{Research questions}

What are nurses' perceptions of self-care priorities focused on the care of older inpatients in acute care settings?

What are nurses' perceptions of the frequency and importance of the daily nursing self-care interventions aimed at older inpatients in acute care settings, based on five types of actions: observing, attending, performing, managing, and informing (Conselho Internacional de Enfermeiros, 2011)?

Are nurses' perceptions of self-care priorities, focused on the care of older inpatients in acute care settings, associated with the sociodemographic variables of gender, age, length of service in the profession, length of service at the current unit, and the number of nursing care hours per older patient week?

Do nurses have different perceptions of the frequency and importance of the daily nursing self-care interventions aimed at older inpatients in acute care settings, based on the five types of actions: observing, attending, performing, managing, and informing (Conselho Internacional de Enfermeiros, 2011)?

\section{Methodology}

A quantitative, exploratory, descriptive, correlational study was conducted to answer the research questions. A convenience sample of 124 nurses was selected among the 536 nurses who were attending Postgraduate programs at a Nursing School (NS) in the center region of Portugal and provided care to older patients in acute care settings. Only nurses who cared for acute older inpatients at internal medicine and intensive care/emergency hospital units were included in the sample. Nurses who did not provide care to acute older inpatients were excluded.

Data were collected through a self-administered questionnaire (adapted from Duque, 2009), which was divided into three parts: 1 - Nurses' perception of the priority self-care domains in which they place greater emphasis during their daily care interventions aimed at acute older inpatients, both in terms of frequency and importance (measured on a 10-point Likert-type scale) - self-bathing; self-grooming; self-dressing/undressing; self-feeding; self-hygiene; mo- 
bility in bed; self-transferring; elimination; walking/wandering; self-toileting; 2 - Nurses' perception of the frequency (measured using a Likert-type scale, where 1 - never, 2 - occasionally; 3 - regularly) and importance (measured on a Likert-type scale, where 1 - little important; 2 - important, 3 - very important) of nursing self-care interventions aimed at older inpatients in acute care settings, based on the five types of nursing actions described in the Nursing Interventions Classification (NIC): observing, attending, performing, managing, and informing (Conselho Internacional de Enfermeiros, 2011); 3 - Demographic and professional characterization.

After the validation process, in which the questionnaire was analyzed by experts and pretested in a sample of 20 nurses, data were collected between July and September 2014 during classes. All ethical procedures were ensured and all authorizations were obtained. Participants gave their informed consent, the head of the Nursing School authorized the study, and the Ethics Committee of the Health Sciences Research Unit: Nursing issued a positive opinion (264/03-2015).

Data were organized, classified, and statistically processed using the IBM SPSS Statistics for Windows, Version 22.0. The association between the main variables was analyzed using the Wilcoxon test and Spearman's cor- relation coefficient. The level of significance was set at 0.05 .

\section{Results}

Most of the 124 sampled nurses were women $(n=100 ; 80.6 \%)$ and married $(n=61 ; 50.0 \%)$, had a Bachelor's degree in Nursing $(n=115$; $94.3 \%)$, worked in internal medicine units $(n=$ $78 ; 63.9 \%)$, and provided direct care $(n=105$; $86.1 \%)$. Participants were aged 22 to 59 years, with a mean age of 29.8 years $(S D=6.75)$. They had been working as nurses for 2 to 37 years, with a mean length of service of 12.84 years $(S D=7.62)$. Nurses reported a mean number of 35.5 nursing care hours per older patient week $(S D=8.27)$.

With regard to the participants' perceptions of the most frequent priority nursing foci in the care interventions aimed at acute older inpatients, the results showed higher scores in the following self-care activities (Figure 1): self-grooming, $(\mathrm{M}=8.02 ; S D=2.56)$, self-dressing/undressing $(M=6.72 ; S D=2.43)$, and self-transferring $(\mathrm{M}=5.89 ; S D=2.40)$. On the opposite, lowest scores were found in self-feeding $(\mathrm{M}=3.64 ; S D=2.86)$, mobility in bed $(\mathrm{M}=4.44 ; S D=2.98)$, and elimination $(\mathrm{M}=$ 4.64; $S D=2.44)$. Hence, participants' priority nursing foci are self-grooming, self-dressing/undressing, and self-transferring.

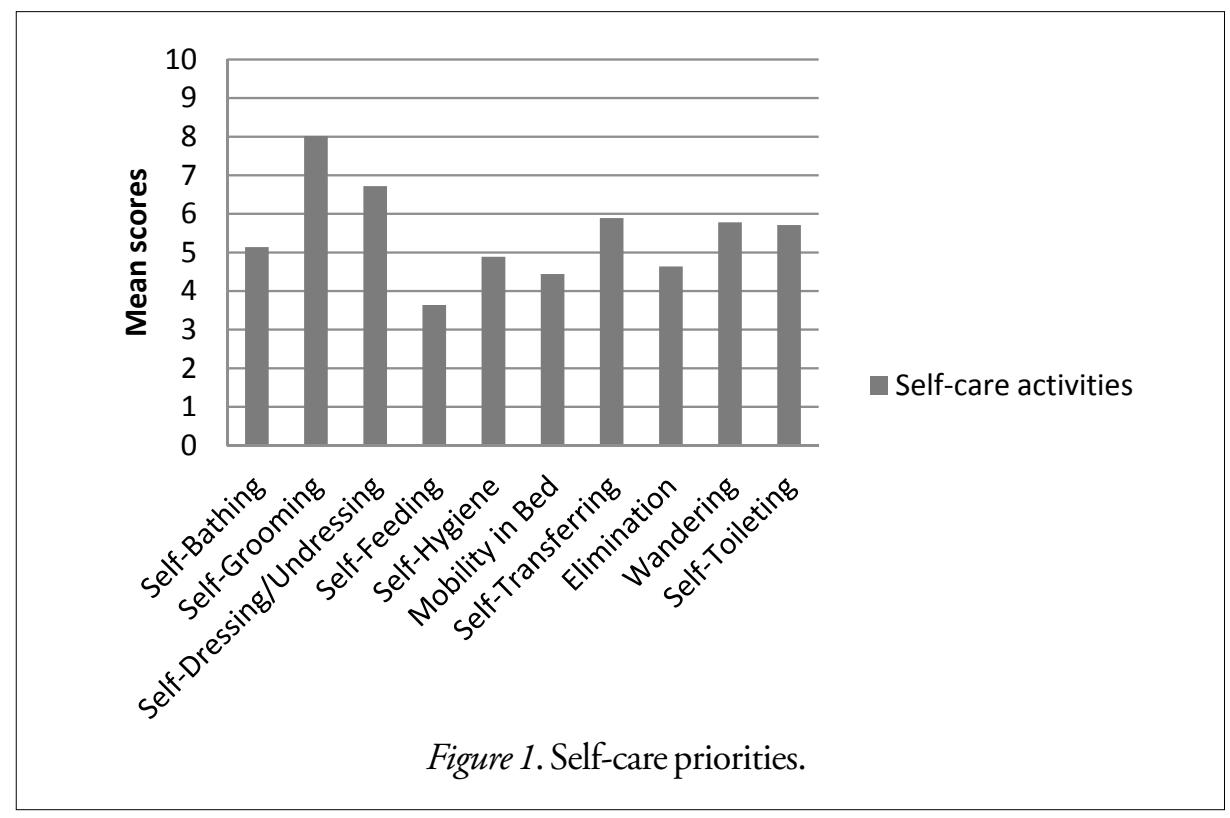


Based on the five types of interventions described in the Nursing Interventions Classification (NIC) - observing, attending, performing, managing, and informing (Conselho Internacional de Enfermeiros, 2011), the results on nurses' perceived frequency of self-care nursing interventions aimed at older patients (Figure 2) showed that the most frequent interventions were observing (M $=2.98 ; S D=0.338)$ and performing $(\mathrm{M}=$
2.83; $S D=0.378)$. As regards nurses' perceived importance of nursing interventions, the most often reported interventions were observing $(\mathrm{M}=2.94 ; S D=0.233)$ and informing $(M=2.90 ; S D=0.325)$. The results show that nurses have consistent perceptions of the frequency/importance of the nursing interventions of observing and managing, but different perceptions regarding the interventions of performing, attending, and informing.

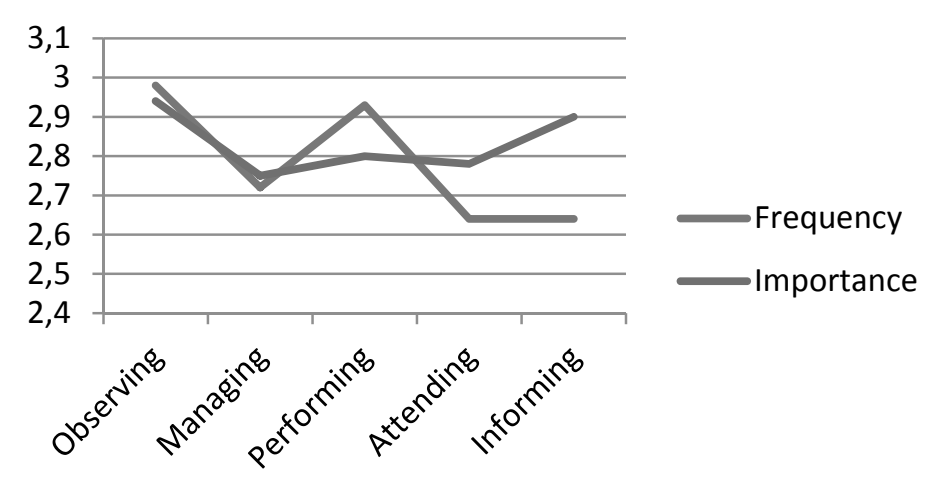

Figure 2. Nurses' perceptions of the frequency and importance of the nursing interventions of observing, managing, performing, attending, and informing.

Significant differences were found between the frequency and importance of the interventions of attending $(Z=-3.272 ; p=0.001)$ and informing $(Z=-4.824 ; p=0.000)$. In other words, nurses have different perceptions of the interventions that they implement most often and the importance, particularly in the interventions of attending and informing.

The only associations found using Spearman's correlation coefficient were the significant negative correlations between the self-care activity of grooming, age $(r=-0.203, p=0.032)$, length of service $(r=-0.194, p=0.041)$, and the number of nursing care hours per older patient week $(r$. $=-0.257, p=0.007)$. In other words, younger nurses, with fewer years of service, and fewer nursing care hours prioritize and place more emphasis on the self-care activity of grooming.

\section{Discussion}

The results show that the participants in this study focus more on the self-care activities of self-grooming, self-dressing/undressing, and self-transferring, which suggests that older people are less capable of carrying out these self-care activities. On the other hand, they focus less on the self-care activities of self-feeding, mobility in bed, and elimination, which suggests that older people have greater autonomy in these activities. These results are partly consistent with the results from the study conducted by Petronilho (2012), in which the nursing foci with higher levels of dependence were walking and self-transferring $(n=31 ; 77.5 \%)$, self-dressing $(n=28 ; 70.0 \%)$, and self-toileting $(n=$ 23 ; 57.5\%), whereas self-feeding $(n=13$; $32.5 \%$ ) was the nursing focus with a higher level of autonomy. The same does not apply to the results of the study conducted by Duque (2009), in which the self-care activities with higher levels of dependence were self-feeding $(\mathrm{M}=3.36)$, self-turning $(\mathrm{M}=$ 3.29), self-lifting $(\mathrm{M}=3.25)$, self-hygiene 
$(M=3.23)$, and self-grooming $(M=3.20)$. According to the sampled nurses' perceptions, older inpatients display greater difficulties in physical activities, namely in dressing/undressing, grooming, and transferring, which may be associated with patients' decrease in strength and loss of movement coordination. Nurses should be aware of these outcomes, which result from personal risk factors associated with lack of mobility (Osuna-Pozo et al., 2013), patients' low ADL and IADL (Hoogerduijn et al., 2012), and increased FD in ADLs and IADLs when comparing between pre-admission, admission, and clinical discharge (Cação, 2017).

To improve the patient's condition, nurses should focus their therapeutic approach on the body processes of muscle strength and joint movement (Petronilho, 2012).

According to the nurses, the interventions of observing and performing were more often implemented, and observing and informing were the most important ones. Thus, observing is not only implemented more often, but it is also considered to be one of the most important nursing interventions. However, although informing is perceived as an important intervention, it is not implemented very often, which may compromise the involvement of informal caregivers. According to Admi et al. (2015), the involvement of informal caregivers is a key psychosocial risk factor in the health/illness transition process. Furthermore, nurses have consistent perceptions of the interventions observing and managing, and different perceptions of performing, attending, and informing. These results suggest that, despite considering attending and informing to be important, nurses do not implement these interventions very often. On the opposite, nurses do not consider performing to be important, but implement it very often. The significant differences found between the frequency and importance of attending $(Z=-3,272 ; p=0.001)$ and informing $(Z=-4,824 ; p=0.000)$ substantiate the analysis above. The results suggest that nurses have different perceptions of the interventions that they implement more often and their importance, particularly in what concerns attending and informing.

These results are consistent with the results obtained by Duque (2009), who found that nurses implemented the interventions of attending, performing, and observing more often, while informing and managing less often. According to the author, nurses perceive that they implement some interventions (i.e., attending, performing, and observing) more often than necessary, while implementing others (i.e., informing and managing) less often than necessary.

In line with the studies conducted by Duque (2009) and Boltz et al. (2011), the results of this study also suggest that the nurses in our sample tend to act for the older person, often replacing him/her, rather than implement a nurse/patient partnership and promote selfcare skills through education. On the other hand, the planning and systematization of nursing interventions for self-care promotion are somewhat inconsistent, since nurses perceive that they implement more often interventions that are seen as less important, and vice-versa.

In addition, the results suggest that younger nurses, with fewer years of service, and fewer nursing care hours give increased attention and priority to the self-care activity of self-grooming. This may be explained by the fact that nurses who are younger, less experienced, and have less contact with older people have less negative SRs about aging and this specific group of patients. Indeed, SRs may condition nursing care in the promotion of older patients' participation in their care and decision-making. Potential indicators of less positive SRs include age, gender, level of education/knowledge, clinical experience, institutional/organizational culture, and community and geographical influence (Boltz et al., as cited in Cruz et al., 2015).

On the one hand, nurses should assess their own attitudes and behaviors towards older inpatients to improve their performance, and, on the other hand, institutions and their leaders should develop and test a set of clinical, organizational, and structural measured to assess the effectiveness of organizational nursing support and create flexible and functional geriatric care models (Carvalhais \& Sousa, 2011).

These results allow concluding on the need for a more positive perspective about older 
people by eliminating any prejudices and negative SRs that nurses may have through the implementation of new strategies both in initial and lifelong training (Cruz et al., 2015). Personal and professional development must certainly involve a change in the attitudes and behaviors towards older people, as well as a shift of focus to personal risk factors (lack of mobility, ADLs, IADLs), psychosocial factors (involvement of informal caregivers), and factors related to the clinical setting. The latter concern the human resources and the nurse/ patient ratio, which is below the average in OECD counties and has been decreasing in the National Health Service over the past few years (OPSS, 2015).

Despite the efforts to maintain accuracy in the methodology and data analysis, the study had some limitations, namely biases that may have emerged from the use of a convenience sampling technique. For this reason, results should be generalized with caution. In addition, the identification of the priority nursing foci under analysis was hampered by the difficulties encountered when describing some foci with overlapping characteristics and using instruments for measuring perceptions of priority nursing foci that require a more consistent validation.

\section{Conclusion}

Based on the research objectives and questions, this study allowed describing nurses' perceptions of priority nursing foci in the most common interventions aimed at older patients in acute care settings hospitalized in acute phase, as well as identifying their association with sociodemographic and professional variables.

The promotion of mobility does not seem to be a priority focus in nursing interventions aimed at older inpatients, which may compromise their autonomy in self-care. Nursing interventions for self-care promotion are not systematically planned, since nurses implement more often interventions that they perceive as less important, and vice versa.

Younger nurses, with fewer years of service, and fewer nursing care hours give more attention and priority to the self-care activity of grooming.
Thus, the initial and lifelong training of nurses and other health professionals, together with institutional strategies, should have a more positive and appropriate perspective about the new paradigm - self-care dependent older people.

Nurses' training and personal and professional development should take place within a more current paradigm, and nurses should shift their attention to individual, psychosocial, and clinical risk factors. This paradigm shift will allow a more accurate evaluation of older people's needs, the identification of factors that may influence processes of adaptation and health/disease transition, the elaboration of correct diagnoses, and the planning and implementation of more effective nursing interventions aimed at functional improvement and reeducation for the performance of self-care.

The lack of studies on this topic calls for the development of more research on self-care and care delivery in these settings, namely by using different and experimental methodologies to systematically assess the strategies' effectiveness.

\section{References}

Abreu, W. C. (2011). Transiçôes e contextos multiculturais ( $2^{\mathrm{a}} \mathrm{ed}$.). Coimbra, Portugal: Formasau.

Admi, H., Shadmi, E., Baruch, H., \& Zisberg, A. (2015). From research to reality: Minimizing the effects of hospitalization on older adults. Rambam Maimonides Medical Journal, 6(2), e0017. doi:10.5041/RMMJ.10201.

Assunção, A. (2015). Readmissóes entre os idosos nos hospitais públicos em Portugal continental. XLIII Curso de Especialização em Administração Hospitalar (2013-2015). Lisboa, Portugal: Escola Nacional de Saúde Pública.

Boltz, M., Resnick, B., Capezuti, E., Shabbat, N., $\&$ Secic, M. (2011). Function-focused care and changes in physical function in Chinese American and non-Chinese American hospitalized older adults. Rehabilitation Nursing, 36(6), 233-240.

Cação, D. (2017). Declínio funcional do doente submetido a cirurgia do aparelho digestivo (Master's dissertation). Escola Superior de Enfermagem de Coimbra, Portugal.

Carvalhais, M., \& Sousa, L. (2011). Promover a quali- 
dade de cuidados de enfermagem a pessoas idosas hospitalizadas. Revista de Enfermagem Referência, 3(3), 75-84. doi: 10.12707/RII1058

Conselho Internacional de Enfermeiros. (2011). CIPE versão 2: Classificação Internacional para a Prática de Enfermagem. Lisboa, Portugal: Ordem dos Enfermeiros.

Cruz, A., Tosoli, A., \& Parreira, P. (2015). Representaçóes sociais sobre o envelhecimento de enfermeiros cuidadores de pessoas idosas hospitalizadas. Revista Investigaçâo em Enfermagem, 2(12), 39-51.

Duque, H. (2009). O doente dependente no autocuidado: Estudo sobre a avaliação e acção profissional dos enfermeiros (Master's dissertation). Instituto de Ciências da Saúde da Universidade Católica Portuguesa, Lisboa.

Faria, C. (2012). Representaçôes sociais de velhice em contexto de prestação formal de cuidados (Master's dissertation). Universidade da Madeira, Portugal.

Instituto Nacional de Estatística. (2017). Projeçôes de população residente 2015-2080. Lisboa, Portugal: Autor

Hoogerduijn, J. G., Buurman, B. M., Korevaar, J. C., Grobbee, D. E., de Rooij, S. E., \& Schuurmans, M. J. (2012). The prediction of functional decline in older hospitalised patients. Age Ageing, 41, 381387. doi:10.1093/ageing/afs015.

Lafont, C, Gérard, S, Voisin, T, Pahor, M, \& Vellas, B. (2011). Reducing "iatrogenic disability" in the hospitalized frail elderly. The Journal of Nutrition, Health \& Aging, 15(8), 645-660.

Observatório Português dos Sistemas de Saúde. (2015). Acesso aos cuidados de saúde. Um direito em risco? Lisboa, Portugal: Autor.

Osuna-Pozo, C. M., Ortiz-Alonso, J., Vidán, M., Ferreira, G., \& Serra-Rexach, J. A. (2013). Revisión sobre el deterioro funcional en el anciano asociado al ingreso por enfermedad aguda. Revista Española de Geriatría y Gerontología, 49(2),77-89. doi.org/10.1016/j.regg.2013.08.001

Passos, J., Sequeira, C., \& Fernandes, L. (2014). Focos de Enfermagem em pessoas mais velhas com problemas de saúde mental. Revista de Enfermagem Referência, 3(2), 81-91. doi.org/10.12707/RIV14002

Petronilho, F., Magalhães, M., Machado, M., \& Vieira, M. (2010). Caracterização do doente após evento crítico: impacto da (in)capacidade funcional no grau de dependência no autocuidado: Revista Sinais Vitais, 88, 41-47.

Petronilho, F. (2012). Autocuidado: Conceito Central da Enfermagem. Coimbra, Portugal: Formasau.

Sidani, S. (2011). Self-care. In: D. M. Doran (Ed.) Nursing outcomes: State of the science. ( $2^{\mathrm{a}} \mathrm{ed}$., pp.131-200). Sudbury, MA: Jones \& Bartlett.

Tavares, J. P. (2014). Avaliação do perfil de cuidado de enfermagem geriátrico em hospitais de Portugal. (Doctoral thesis), Universidade de Aveiro, Portugal. Retrieved from https://ria.ua.pt/handle/10773/12968 
